\title{
The Dynamic of Infaq and Sadaqah: According to the Social Facilitation Theory
}

\author{
Nelly Marhayati \\ nmarhayati@iainbengkulu.ac.id \\ State Islamic Institute of Bengkulu
}

\begin{abstract}
The present study purpose to examine the individual dynamic of infaq and sadaqah according to social facilitation theory. Infaq and sadaqah referred to charity that was considered as vertical relationship between God and human, and it was Sunnah for both terms. Some Muslims find difficulties and do without sincerity when perform these deeds and acts, which is also similar to others worship. According to social facilitation theory, individual performance will enhance as another individual gets involved together. Phenomenology approach and analysis of interview data employed in this study revealed that social dynamics in individual behavior was increasing to perform infaq and sadaqah as people with same behavior emerged. However, individuals who considered infaq and sadaqah as worship, the presence of others did not affect to individual's behavior.
\end{abstract}

Keywords : Infaq and Sadaqah, Social Facilitation Theory 


\section{INTRODUCTION}

Basically, human as social being since always been social creatures which need help from others, especially in meeting personal and public need. Islam ideology objective to bring prosperity, grace, and peace for human being in the world let people to help each other. Allah SWT has delivered enormous natural sources in case human being takes the benefit wisely.

Based on survey and a study conducted by CAF (Charities, Aid, Fondation), non-profit organization based in Great Britain, Indonesia is in the first the most generous country in ther world. The result was identificated by $78 \%$ of Indonesians who love donating their money to sesame, $53 \%$ of volunteer, and desire to help foreign people by $46 \%$. It indicated that Indonesians, generally, are very generous despite their background, ethnicity, and race. Moreover, Pancasila values of helping each other have been rooted by society. However, this value fades the nation's identity since post-truth politics emerges.

Islam value of helping others is presented in Muslim obligation to pay zakat, as well as Sunnah charity like infaq and sadaqah. Zakat is one of five pillars of Islam to which all members are required to perform. It has been stated in the Qur'an that less than 28 ayat (verses) mention the obligatory to pay zakat, for example in surah Al-Baqarah: 43, "And establish prayer and give zakah and bow with those who bow [in worship and obedience]". Zakat is beneficial for Muslims to acknowledge everything they have and do not really own it. Economically and socially, zakat is considered for prosperity and equity for every human being, specifically for Muslims. These good deeds, zakat, infaq, and sadaqah are part of generosity behavior (philanthropy) of Muslim. Habib asserted that collected zakat, infaq, and sadaqah by Amil (the zakat collectors) in order to make the distribution easier to the proper recipients [1].

In aforementioned explanation, zakat is a religious obligation by giving specified properties that have reached the amount of nisaab to the certain needy people based on the specific percentage. Infaq and sadaqah are giving some possession or income that have ordered in Islam regardless the nisaab and percentage. Every moslems gives infaq and sadaqah despite the time and place. The differences between both terms are infaq is more about giving materially than sadaqah which has broader meaning. Sadaqah is included either material or non-material [2].

\section{THEORITICAL FRAMEWORK}

Infaq is originated from anfaqa, refer to spending (possession) for certain importance, including infaq that is disbursement of religious-based importance. In islamic terminology, infaq is spending as has been ordered by religion. If zakat is given to mustahiq ( 8 groups), infaq can be given to anyone, for instance parents, relatives, the poor, the orphan, or people who intention of travelling (musafir). It can be stated that infaq is a voluntary spending regardless the threshold and person who is given [3].

Islamic law has given the guidance to Muslim in terms of infaq and spending their possession. This has been mentioned in Quran and hadith that Muslim should perform infaq by giving certain properties and spend their own properties for theirselves (QS. At-Taghabun: 16). Likewise, a man provides wife and family from his wealth based on his capabilities (AtTalaq: 7). Lastly, property that is spend or infaq is a good property (QS. Al-Baqarah: 267).

Some previous studies related to present a study in factors that affects to individual participation for zakat [4]. Result of this study shows that there were 5 factors that influence 
individual participation in performing zakat, encompass organization, altruism of social sensitivity, appreciation, satisfaction, and faith.

Study entitled motivation of paying income zakat in order to pursue study in Malaysia suggests that the main factor in which influences someone to pay is belief in terms of religious-based obligation [5]. Therefore, they believe that possession is given to the poor and the needy and zakat as financial help for needy people. In this study, it is found that motivation in paying income zakat was due to tax deduction by government and facilities provided by zakat collectors.

A study about the analysis of influential factors of participation level and zakat and infaq collector organization choices. The study suggests that there are factors which influence individual to pay infaq regularly; it encompasses faith, altruism, satisfication, education, and infaq frequency [6]. Nevertheless, factors that influence the choice where people pay zakat are educational factors and the existence of zakat collector organization (OPZ).

Beik and Alhasanah [7] find that factors which influence participants to zakat are faith, altruism, appreciation, organization, and income. In addition, for infaq, it encompasses faith, altruism, satisfaction, education, and infaq frequency. The results indicate that internal factor dominate infaq behavior as well as sadaqah within individuals.

Zein's [8] study entitled factors that influence infaq awareness among congregrations Islamic community of Great Mosque of Yogyakarta find that the most influential variable to infaq awareness among congregrations is the role of Islamic scholar as well as income collected lead them to perform infaq. Unlike the present study, the previous study highlights the external factors that influence the infaq behavior of individual.

According to previous studies, it reveals that behavior change of infaq and sadaqah occurs is due to two factors, internal and external factor. Internal factor comes from individual physical factors, such as life attitude, life value, and changing thinking pattern. Moreover, external factor encompasses time, science and technology development, information, communication, as well as socio- culture.

The involvement of companion, according to drive theory, leads to improvement of individual performance when dealing with activities, however not to mention also possible could lower individual behavioral performance [9] [10].

According to drive theory people relatively unpredictable (people rarely know what will happen), there is clear advantage to the people for the presence of those cause us to be in a state of alertness and readiness. The social presence could be increased arousal performance of individu. If the dominant response is correct, than social presence could be enhanced performance, if it is incorrect, then social presence could be decrease performance [11].

In social psychology audience effect is named with social facilitation theory. The Social facilitation theory was initiated by Triplett (1897-1898) in his experiment toward racing athlete in 1897. The research suggested that the athlete who competed other athletes got a good achievement, compared to those who competed time. The presence of other athletes at the competition eventually has activated the athlete intuition to compete, as a result energy and performance arouse. Additionally, Triplett re- examined his research results to a group of children who participate in fishing contest, either in a pair or solo. The result shows that those who fish together collects more fish than those who fish alone [12].

Social facilitation may therefore lead to an increase or decrease in performance, depending on what the dominant response is in that social context. Research has been generally supportive of drive theory predictions. Individuals are more likely to emit dominant responses in the presence of others than when alone, and performance is either enhanced or impaired 
depending on the match of the dominant response to the performance being measured [13].

On the other hand, in fact, the presence of others is not always affects on someone's performance, but they also can lower individual performance. Robert Zajonc [9] finds that person's attendance increase individual performance. However, the effect to the performance itself depending on the task performed. This finding is called as the Zajonc Solution where contains of three steps as follows:

1. The presence of others will lead to non specific drive, also referred to diffuse arousal that will drive individual behavior

2. Enhances individual's tendency to perform the dominant response. This response elicits after stimulus given.

3. Individual performance varies with the type of the task. Easy task commonly lead to correct response, while difficult task will create incorrect response.

Increased performance while performs easy task and lower while carries out difficult task, it has been defined by Zajonc as social facilitation [12].

Another researcher suggests that the presence of others will lower the individual performance since they are frightened [14]. Likewise, McLeod [14] suggests that social facilitation is defined as enhanced individual performance because of the presence of others. There are two types of social facilitation, co-action and audience effect. Co- action effect refers to other's involvement in individual activity. Audience effect is the influence of the presence of others in individual activity. This study is focused on social facilitation with broder understanding of individual behavior in which influenced by the presence of others either directly or indirectly.

Research findings of Thomas, Skitka, Christen, and Jurgena's [13] related to social facilitation and formation impression indicate that the presence of others also affect on process of individual social assessment to a condition. Regarding to drive theory, eventhough the presence show unspecifically, increased behavior will be occurred.Although drive theory is designated the prediction of behavior, there are unspecific reasons emerge that will influence social assessment and behavior shaping. The process of this social shaping is given by positive perception or individual negative to social facilitation provided.

Uziel [15] in his meta-analysis finds that the presence of others in social facititation is influenced by moderator variable, namely personality factor. This factor gives more impact to whether individual performance increase or decrease in a situation, rather than difficulty level performed by individual differences. individual differences in susceptibility to the influence of social presence, this time with regard to mental functions (thought and association) [15]. The presence of others as a participant, supporter, or audience, is eventually enhances individual performance to the tasks performed.

Drive theory of social facilitation describe more that the presence could increase as well as decrease individual performance depending on other's response given to the task offered. The situation whether these people support or not the task accomplished by individuals, further explanation about distraction conflict in social facilitation theory will be elaborated. Distraction occurs when the presence of others tends to cause conflict, which is whether the presence support or discourage the ongoing activity [16].

According to previous studies and given explanation above, it is assumed that the presence of others in an event gives an impact to others; the impact could be positive or negative. Some of studies highlighted the achievement occured among athlete and students at school. However, the previous studies overlook the presence of others during the process of performing infaq and sadaqah. Hence, the researcher needs to know the validity of previous studies that examine external factor of individual when performing infaq and sadaqah related to socio-cultural factor. Initial observation by the researcher indicates that enhanced amount 
of infaq and sadaqah occurs by employing infaq donation box. Regarding to this case, the researcher attempts to identify whether increased amount is due to the presence of others in an event or other factors.

\section{RESEARCH METHODS}

Positivistic paradigm that emphasizes more on the quantitative aspect in psychology is considered as the implementation of principals in natural science into psychology field. Thus, some experts of alternative psychology study consider that positivistic approach do not provide spaces for choices, freedom, individuality and social responsibility existed in human beings as an object of study in psychology. The consequence of this dissatisfaction motivates the emergence of a new methodology that can complement the limitations of positivistic approach. According to Smith (1995) in Hanurawan [17], the development of this new approach is built on some basic principles:

1. Psychological study should be carried out in real-life or natural settings.

2. Psychological study needs to recognize the main role of language and discourse in the construction of psychological symptoms.

3. Human life and psychological study are understood as activities that take place in a reciprocal process or as interactive and dynamic activities.

4. Psychological study should be interested in psychological symptoms that are personal and individual rather than symptoms that are measured in form of variables and that involve subjects with a large group scale.

Qualitative research with phenomenology approach was employed in this present study. Phenomenology approach is an approach in qualitative research that is attempted to describe awareness, individual or public experience of activity or individual condition. The phenomena referred to is also described as a particular object and someone's empirical experience in which defined by that person.

Phenomenological approach model is a research procedure by looking at the phenomena that are happening in society. This model of approach emphasizes the way humans as research subjects interact with symptoms or phenomena that occur in society, both towards empirical objects and an event. The phenomenological approach is closely related to individual cognitive abilities. According to this approach, individuals, as cognitive, linguistic, and affective beings, have a relationship with speech, thoughts and emotional status. Relationships that occur between these three things are very complicated, so that individuals find it difficult to express what they think and feel. This makes the reason why individuals do not want to reveal themselves, so researchers must interpret the mental and emotional status of what is said by the individual.

The phenomenology approach can be used when a researcher wants to find out how individuals perceive certain situations that are being faced, and understand their personal and social conditions. This approach is particularly useful when the individuals are faced with complexity, process or something new [18].

There were 20 students of $3^{\text {rd }}$ semester involved as informants, consisted of 8 men and 12 females. All informants were asked three open-ended questions. After that, the researcher attempted to find the answer written by the informants. The answers were analyzed how the dynamics of infaq and sadaqah presented by means of social facilitation theory.

Deducting the informants' answer was employed as data analysis technique. The answer was correlated to major theme in which designated the significance of individual experience. 
This experience was about infaq and sadaqah according to facilitation social theory. During analyzing the data, the researcher looked out and explored the words and sentences within the answer, which was significant to research objective.

\section{RESULTS}

The first question addressed to the informant was "Do you prefer giving infaq to mobile or settled donation box?" The answers were varied as the following:

"I prefer settled to mobile infax donation box because more convenient not to see by others. It also to respect those who cannot donate for infaq" (LF, the informant)

"I prefer settled infaq donation box due to can not be recognized by others that I have been donated, it is also keep me away from riya' (in Arabic word means ostentation)". (AS, the informant).

"I prefer to give in settled box than mobile box. For me, giving alms is no need to show off because Allah is the omniscient, the all-knowing to everything we have done. It is also more private". (YO, the informant).

"Settled infaq donation box is better since people feel being forced by mobile box. If the box is at place, therefore the person has willingness to give infaq" (WD, the informant).

"I prefer settled alms box because I assume that alms giving comes from your own without asking from others". (RJ, the informant).

"In my opinion, if you really want to give infaq, it does not have to be known by everyone. Only God and we knows, based on intention (innam akmalu binniat) or give it secretly". (KM, the informant)

"I prefer infaq donation box which is not turning around. It is because, for me, I don't like that way, because infaq is a good deeds we should do, without asking. Our Rizq (material provision) is also others', so that it is reasonable by giving one another a little of our possession". (NP, the informant)

The informants above preferred the settled to mobile donation-box, because these reasons: infaq and sadaqah come from your own without asking from others, considered as personal interest, kept someone's away from riya', felt displeasure to be recognized, and looked to be forced.

In the contrary, some informants preferred mobile infaq donation box because as follows:

"More pleasure with mobile donation box because I get initiative to give infaq and sadaqah if I am being asked". (IS, the informant).

"The mobile donation box reminds people and me to give infaq". (DH, the informant). 
Based on the two informants above, they choose mobile infaq donation box since people action motivates them to give infaq.

The second question proposed by the researcher is "Does the amount of someone's infaq give impact to yours?" This question brings various answers as follows.

"This does not affect to the nominal I will spend because I usually give infaq according to the financial conditions, so if there are other people give more than me, I will still in my decision for the amount. Further, if other people give less from me, I will spend as I want to (NP, the informant) ".

"It will not affect on me at all because alms giving regardless the amount you will spend, but the intention of giving and voluntarily (RJ, the informant).

"It does not (the presence of others), due to unnecessary to know other's amount. Essentially, infaq and sadaqah give sincerely, what we possess need to be given".

"It works on me. The more people spend for sadaqah, the more I will spend if I have enough money" (LF, the informant).

"It does not influence me because I know how much I should spend without knowing others. In my opinion, the term infaq and sadaqah are about sincerity and empathy" (YO, the informant).

The answers showed that, commonly, the informants took for granted to the amount people spend for infaq. This case due to infaq and sadaqah were totally depending on someone's ability and sincerity. Only one informant was influenced by others and being motivated to give more. However, it eventually returned to the informant's ability to give.

For the next question, "How do you feel when someone spend for infaq and sadaqah?". Some informants assert that they are being courage to spend for infaq and sadaqah. Nevertheless, some of them argue that they are not affected by the action due to good deeds need sincerity and other people are not allowed to know the amount.

\section{CONCLUSION}

According to the result and discussion, it can be concluded that for worship to God, more specifically infaq and sadaqah, the presence of others or in social psychology known as social facilitation theory consists of two influences. First, others' presence drove individual to perform similar action, which is giving infaq and sadaqah. Second, when the individual realizes infaq and sadaqah are part of religious-based activity with the intention of pleasing to God, the presence of others does not effect upon individual behavior. The informants assert that infaq and sadaqah is a part of worship, needs sincerity and without being asked upon the performance. Finally, the discovery from this research that mere presence can affect perceptions and behavior individu in infaq and sadaqah but other hand mere presence can not affecr perceptions and behavior individu in infaq and sadaqah.

Based on present study, further studies therefore are necessary to determine the individual's performance between worship and motives behind. The motives come internally and externally, whether intention of pleasing to Allah or the presence of others. According to infaq and sadaqah act, Further studies might to explore that's act effect from social media point of view or from cyber media. 
The non-diractional components does not affect the type of individual behavior (performance enhancing or behaviour) only motivation or encouragement that can be specifically influenced by the presence of others.

\section{DISCUSSION}

According to the given data above, it can be assumed that the presence of others in infaq and sadaqah behavior to respondents emerges the dynamic of infaq and sadaqah. In a question about infaq donation box preference, the informants are classified into two types, those who prefer the settled box and those who prefer the mobile box.

Informants who prefer settled box consider the action as self-motivated action so that they avoid riya' and arrogant. Moreover, this religious-based activity need to be kept, only God and that person knows. In contrast, mobile donation box lead the informants to be motivated when they know people perform infaq and sadaqah. It means that although few of them prefer the mobile box, it indicates that the presence of others still give them willingness and motivation of infaq giving.

In order to review how the social facilitation theory employed in infaq and sadaqah giving behavior, the researcher also asked if the informant got the influence of someone's amount to spend infaq and sadaqah. Thus, the answers above revealed that some of the informants were not influenced by it since infaq was about sincerity and informants' ability to spend. Yet, some of them were driven to spend more after looking someone's amount. However, the bigger the amount spent by the informants, the more they consider the ability for infaq and sadaqah.

Likewise, as the third answer about the influence of the presence of others in infaq and sadaqah, some informants agree that infaq and sadaqah are sincere giving without seeking a substitute in return. They also argue that infaq and sadaqa may not be recognized by others despite of the presence of others.

Previous paragraphs elaborate the encouragement lead to individual behavior related to religious-based activity, for instance infaq and sadaqah. An individual becomes much more motivated to perform infaq and sadaqah. When it comes to the amount spent, the informant also triggers to give more for infaq. Eventhough only some of them to do so, indicating that the presence of others can stimulate and enhance others to give infaq and sadaqah.

The findings of previous study show that one of the variables occur in enhancing infaq and sadaqah motivation the congregation of Masjid Gedhe Kauman Yogyakarta is the presence of Islamic scholars as well as their economy condition [8]. The Islamic scholar's suggests the congregations for voluntary giving of alms and charity. In this case, the researcher assumes that the presence of Islamic scholars is similar to the presence of others. However, the Islamic scholars do not participate in the same activity as the congregations did. Thus, it is considered audience effect in the context of social facilitation theory.

The informants' enthusiasm to give more amounts is more likely influenced by internal and personal factor. They assume that performing infaq and sadaqa are advised or Sunnah, consequently the good effects would come after. It is also argued by Rosmini [19] that infaq is accomplished with the intention of pleasing to Allah, given with our own possession that is halal (permitted) and thayyib (good), adjusted with the person's ability.

The Islamic teachings state more specifically about helping others by giving zakat, infaq, and sadaqah. These terms also have been mentioned in ther Quran and Sunnah. Zakat is a 
major charity and one of the five pillars of Islam which is mandatory. Less than 28 ayat (verses) of Quran occurred in reference to the obligatory zakat. Zakat, infaq, and sadaqah are believed that will be beneficial for those who purify their possession. These terms have differences, zakat is considered as obligatory charity, while infaq and sadaqah are Sunnah (non- obligatory charity). Nevertheless, they are all part of philantrophy behavior of Islamic society. They are also supposed to be an important role for economic prosperity in a country $[1]$.

The aforementioned paragraphs suggested that there was behavioral dynamic related to willingness of infaq and sadaqah giving. The dynamic was shown by the emergence of intention to give while others performed infaq and sadaqah, or became much more motivated to perform infaq and sadaqah. Though, the individuals realized that these activities are mandatory in Islamic teachings with the intention to Allah. As a result, they assumed that the presence of others would not change them to give infaq and sadaqah. The summary of behavioral dynamic is presented on the diagram below.

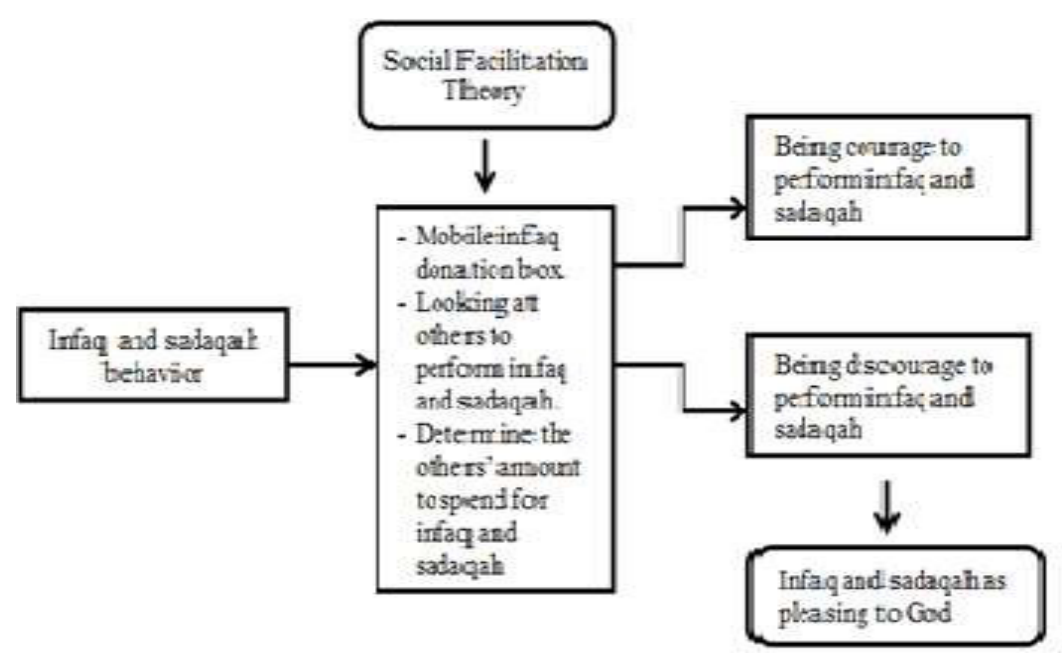

Fig 1. The diagram of behavioral dynamic of infaq and sadaqah

The dynamic of Infaq and sadaqah behavior that occur in individuals because of presence of other people through a charity box that's runs and sees the nominal number of people who invest can increase the desire for infaq and sadaqah and decrease the desire to infaq dan sadaqah. However, there is a behavior that appears that infaq and sadaqah are done because of worship and Allah's commands.

From this research Social facilitation may therefore lead to an increase or decrease in performance, depending on what the dominant response is in that social context, that's mean depending what the most people doing in infaq and sadaqah at one moment. 


\section{REFERENCES}

[1] Habib, A. A., 2016. The Principle of zakat, infaq, and shadaqah accounting based sfas

109. Journal of Accounting and Business Education, 1 (1), September, p. 1-19.

[2] Sanusi, M., 2009. The Power of Sedekah, Yogyakarta: Pustaka Insan Madani.

[3] Hastuti, Q. A. W., 2016. Infaq Tidak Dapat Dikategorikan Sebagai Pungutan Liar. ZISWAF, Vol.3, No. 1, Juni, p. 40-62

[4] Muda, M., Marzuki, A., and Shaharuddin, A. 2006. Factor Influencing Individual Participation in Zakah Contribution: Exploratory Investigation. Paper submitted 68 for presentation at the Seminar for Islamic Banking and Finance 2006 (iBAF2006), 29 - 30 August 2006, Kuala Lumpur (Faculty of Economics and Muamalat, KUIM, Nilai NS). [5] Abu Bakar, N. B., \& Rashid, H. M. A. (2010). Motivations of Paying Zakat on Income: Evidence from Malaysia. International Journal of Economics and Finance, 2(3)

[6] Irfan Syauqi Beik dan Izzatul Mabniyyah Alhasanah. (2012). AnalisisFaktor-Faktor Yang Mempengaruhi Tingkat Partisipasi dan Pemilihan Tempat BerzakatDan Berinfak. Jurnal Ekonomi \& Keuangan Islam. 2 (1), 64-75 Indonesia: Institut Pertanian Bogor.

[7] Beik, I. S. \& Alhasanah, I. M., 2012. Analisis Faktor- Faktor yang Mempengaruhi Tingkat Partisipasi dan Pemilihan Tempat Berzakat dan Berinfak. Jurnal Ekonomi \& Keuangan Islam. Vol.2 No. 1, Januari 2012: 64-75.

[8] Zein, L. L., 2018. Faktor-Faktor yang Mempengaruhi Kesadaran Berinfaq Pada Jamaah Pengajian di Mesjid Gedhe Kauman Yogyakarta, Naskah Publikasi. Yogyakarta: UII.

[9] Zajonc. R. B., 1965. Social Facilitation. Science 149, 296-274 10.1126/science.

149.3681.269

[10] Ukezono, M., Nakashima, S. F., Sudo, R., Yamazaki, A., Takano, Y., 2015. The combination of perception of other individuals and exogenous manipulation of arousal enhances social facilitation as an aftereffect: re-examination of Zajon's drive theory. Front Psychol. V.6: 601. Doi: 10.3389/fpsyg.20015.00601.

[11] Hogg, M. A., \& Vaughan, G. M., 2011. Social Psycholoy, Pearson Education, sixth edition.

[12] Suryanto., Putra, M. G. B. A., Herdiana, I., \& Alfian, I. N., 2012. Pengantar Psikologi Sosial. Surabaya: Airlangga University Press.

[13] Thomas, S. L., Skitka, L. J., dan Christen, S \& Jurgena, S., 2002. Social Facilitation and Impression Formation. Basic and Applied Social Psychology, 24 (1), 67-70

[14] McLeod, S. A., 2011. Social facilitation. Retrieved from http://www.simplypsyhology.org/Social- Facilitation.html.

[15] Uziel, L., 2007. Individual differences in the social facilitation effect: A review and metaanalysis. Journal of Research in Personality, 41, 579-601. Doi: 10.1016/j.jrp.2006.06.008

[16] Branscombe, N. R. \& Baron, R. A., 2017. Social Psychology. 14th edition. United States: Pearson.

[17] Hanurawan, F., 2016. Metode Penelitian Kualitatif Untuk Psikologi. Jakarta: Rajawali Pers

[18] Smith, A., J. 2014., Psikologi Kualitatif Panduan Praktis Metode Riset. Terj: Budi Santoso. Pustaka Pelajar: Yogyakarta.

[19] Rosmini., 2016. Falsafah Infaq dalam Persfektif Islam.Jurnal Madania Vol.20, No.1 Juni. 
